\title{
The presence of Neopterin in the sera of a sample of Iraqi acromegalic patients (Type 2 diabetics and nondiabetics)
}

${ }^{1}$ Department Of Microbiology College Of Medicine Mustansiriyah University, Iraq.

${ }^{2}$ Nantional Diabetes Center (NDC), Mustansiriyah University, Iraq.

Corresponding author: momg83@gmail.com

\begin{abstract}
Acromegaly is a rare endocrine disease; its incidence is 4-6 million per year, while its prevalence is 40-60 million per year. They are separating acromegaly from gigantism that occurs before growth plates are closed. Neopterin is a systemic adaptive immune activation biomarker produced upon interferon-gamma (IFN- $\mathrm{\gamma}$ ) stimulation by monocyte-derived macrophages and dendritic cells. Eighty acromegalic patients (50\% diabetic acromegalic and 50\% nondiabetic acromegalic) and forty healthy control groups were enrolled in the study to find out the level of Neopterin and insulin-like growth factor-1 in the sera of the study population; the results showed both molecules (neopterin and Insulin-like growth factor-1 were found to be high in acromegalic subjects when there is concomitant diabetes, and insulin-like growth factor-1 correlates positively with total cholesterol and neopterin. At the same time, neopterin correlates positively with HbAlc. This study was aimed to find out the difference in neopterin level in diabetic acromegalic versus nOn-diabetic acromegalic patients; Eighty acromegalic subjects were enrolled in across sectional study by measuring the neopterin level in the sera of diabetics and nondiabetics as 39 have diabetes while the remaining 41 patients are nondiabetic. Neopterin is high among diabetic acromegalic patients when compared with nondiabetic acromegalic subjects. Insulin-like growth factor-1 correlates positively with neopterin and total cholesterol; (4) Conclusions: Across sectional-study enrolling eighty acromegalic patients registered in the National Diabetes Center. Thus they were subdivided into two groups: - diabetic and nondiabetic the level of neopterin was found to be among diabetic versus nondiabetics.
\end{abstract}

Key words: Neopterin, Diabetic Mellitus, Acromegaly.

\section{Introduction}

Acromegaly is a chronic and rare condition caused by pituitary adenoma, resulting in increased growth hormone secretion. High growth hormone concentrations induce the liver to secrete insulin-like growth factor-1(IGF-1), resulting in unacceptable changes in the patient's form and changes in the body, as well as skeletal anomalies ${ }^{1}$. Acromegaly's hallmark characteristics include hand and foot enlargement, prominent supraorbital ridges, hyperhidrosis, seborrhea, and related comorbidities such as diabetes mellitus, elevated blood pressure, heart failure, and osteoarthritis². Growth hormones are involved in inhibiting the function of insulin, like inhibiting the phosphorylation of insulin receptors, among the most significant aspects of insulin production. As a result, the insulin sensitivity of the cells will decrease, encouraging peripheral glucose absorption in the periphery and increasing resistance to the gluconeogenesis suppression ability of insulin. Hence, the increase in growth hormone production leads to free fatty acids and avoids insulin-induced glucose oxidation, resulting in further deterioration of insulin resistance, contributing to diabetes mellitus ${ }^{3}$.

Impaired glucose metabolism is typical in acromegaly patients, owing to impaired insulin sensitivity caused by high $\mathrm{GH}$ and IGF-1. Diabetes mellitus (DM) is one of the most common comorbid disorders linked to an elevated risk of cardiovascular death in people with acromegaly ${ }^{4,5}$. (NEOP) is253D pteridine molecular weight compound pyrazine pyrimidine molecular weight compound pyrazine-pyrimidine molecular weight compound pyrazine-pyrimidine molecular weight compound pyrazine-pyram Pteridine is a chemical compound made up of pyrimidine and pyrazine rings. A pteridine is a class of heterocyclic compounds that can have a variety of substituents in their structure.

Pterins and flavins are a type of pteridine that has critical biological features. It is produced when $T$ lymphocytes are activated by guanosine triphosphate (GTP) and -interferon (INF)$^{6}$. When monocyte-derived macrophages and dendritic cells are stimulated to create interferon-gamma (IFN-), neopterin is produced, and it is regarded as a suitable proxy for measuring the rate of IFN- production ${ }^{7-10}$. Neopterin concentrations increase with the dose of interferon, thereby helping to control the activity of inducible inflammation of INF- $\gamma$. Therefore, the measurement of neopterin levels in body fluids provides information on the activation of systemic adaptive immune activation derived from T-helper cells ${ }^{11}$.

\section{Materials and methods}

Eighty acromegalic patients (thirty- nine(39) diabetic acromegalic and forty-one (41) nondiabetic acromegalic patients

Citation: Hamodi Hamza S, Fadhel Ashoor Z, Mahdi Rahmah A. The presence of Neopterin in the sera of a sample of Iraqi acromegalic patients (Type 2 diabetics and nondiabetics). Revis Bionatura 2022;7(1). 25. http://dx.doi.org/10.21931/RB/2022.07.01.25

Received: 2 October 2021 / Accepted: 20 November 2021 / Published: 15 February 2022

Publisher's Note: Bionatura stays neutral with regard to jurisdictional claims in published maps and institutional affiliations. 
attending the National Diabetes Center (NDC)/Mustansyriah University were enrolled in the study and compared with40 control subjects that were defined by achieving the goals (pituitary adenoma, size regression, Insulin-like growth factor-1 and growth hormone decrement down to the recommended, predefined targets) ${ }^{12}$. They were subdivided into subgroups according to their age, gender, lipid profile, concomitant diabetes and glycemic control in diabetic patients. Neopterin was measured using enzyme-linked immune-sorbent assay(ELISA), which is done utilizing Human Neopterin (NEOP)ELISA kit was sandwich methodology. The Micro ELISA plate provided in this kit has been pre-coated with an antibody specific to NEOP. Correlation between NEOP and other biochemical and clinical variables was studied using Pearson correlation methodology. Statistical package of social science (SPSS) _ version 27 was used to analyze the data.

\section{Results}

Eighty acromegalic patients were recruited, thirty-nine (39) are diabetics, and the other forty-one (41) are nondiabetics, while the control group includes forty (40) nondiabetic non-acromegalic healthy persons. All the recruited patients are registered in the National Diabetes Center (NDC)/ Mustansyriah University. The results of age and gender were presented in Table (1). The age was ranged from 25-78 years, and the more percentage of diabetic acromegalic patients was shown within the age group (40-49years) As they represent $(46.2 \%)$ of patients. Neopterin levels are highest in diabetic acromegalic patients under 50 , followed by nondiabetic acromegalic patients, and finally, the control group. Neopterin levels are higher in male diabetic acromegalic patients than in nondiabetic acromegalic patients, while the opposite is true in the control group, but this steady decline is not statistically significant. The usual range of serum neopterin is (3-100). Neopterin is high among diabetic acromegalic patients, followed by nondiabetic acromegalic patients and, finally, the control group. As revealed in table (2).

Table (3) shows that: The level of Neopterin is the lowest among the control group versus diabetic acromegalic and nondiabetic acromegalic patients. Normalization of HDL is associated with elevation of Neopterin in diabetic acromegalic and nondiabetic acromegalic patients. Elevation of LDL is associated with high Neopterin in diabetic acromegalic, followed by nondiabetic acromegalic patients. However, the difference did not reach statistical significance. The lowest VLDL is associated with a higher neopterin in diabetic patients when compared with another study group. The highest cholesterol level was correlated with the highest neopterin level, whereas diabetic acromegalic was followed by nondiabetic acromegalic patients and the control group. Elevation of triglyceride value is associated with high Neopterin in diabetic acromegalic followed by nondiabetic acromegalic; the impact of high triglyceride on Neopterin level is true in the control groups as well. Neopterin is the highest in non-acromegalic when their $\mathrm{HbAlC}$ is high (does not fulfill the definition of diabetic ranging from 5.7-6.4\%), the level of Neopterin drops in diabetic acromegalic subjects when their glycemic control is poor. Normalization of $\mathrm{GH}$ is associated with lower Neopterin levels among nondiabetic acromegalic subjects versus diabetic acromegalic subjects. The highest number og diabetic acromegalic(36) patients have anormal value of, IGF-1which shows a mean for neopterin in higher (89.85) than that of nondiabetic or control groups(41-78). The diabetic acromegalic patients also showed a higher neopterin level, which was associated with a highest value for IFN-Y compared with nondiabetic acromegalic patients or the control group.

\section{Discussion}

Table -1Shows that most of the acromegalic patients are within the age group of 40-49 years at the time of diagnosis, while few patients are group 30-39, and no acromegalic subjects were registered his age is less than 30 years. The median age of acromegalic, as stated by (13) in Duhok province, was (44.9 years). The median age agrees with (14), who found that it is ( $49.2 \pm 8.9$ years) in Bagdad province. The explanation of the results of age that acromegaly disease. Most people are diagnosed in their third or fourth decade of life. Recent studies, however, have revealed an increase in the incidence and fre-

\begin{tabular}{|c|c|c|c|c|c|c|c|c|}
\hline & & \multicolumn{2}{|c|}{$\begin{array}{c}\text { Diabetic } \\
\text { Acromegaly }\end{array}$} & \multicolumn{2}{|c|}{$\begin{array}{l}\text { Nondiabetic } \\
\text { Acromegaly }\end{array}$} & \multicolumn{2}{|c|}{ Healthy control } & \multirow[t]{2}{*}{ P-value } \\
\hline & & No & $\%$ & No & $\%$ & No & $\%$ & \\
\hline \multirow{5}{*}{$\begin{array}{c}\text { Age } \\
\text { (years) }\end{array}$} & $<30$ years & - & - & 1 & 2.4 & 4 & 10.0 & 0.067 \\
\hline & $30---39$ & 3 & 7.7 & 9 & 22.0 & 7 & 17.5 & \\
\hline & 40----49 & 18 & 46.2 & 12 & 29.3 & 16 & 40.0 & \\
\hline & 50---59 & 10 & 25.6 & 16 & 39.0 & 9 & 22.5 & \\
\hline & $\Rightarrow>60$ years & 8 & 20.5 & 3 & 7.3 & 4 & 10.0 & \\
\hline \multirow{3}{*}{$\begin{array}{c}\text { Age } \\
\text { (years) }\end{array}$} & $<50$ years & 21 & 53.8 & 22 & 53.7 & 27 & 67.5 & 0.354 \\
\hline & $\Rightarrow>50$ years & 18 & 46.2 & 19 & 46.3 & 13 & 32.5 & \\
\hline & $\begin{array}{c}\text { Mean } \pm \text { SD } \\
\text { (Range) }\end{array}$ & \multicolumn{2}{|c|}{$\begin{array}{c}51.1 \pm 10.6 \\
(30-78)\end{array}$} & \multicolumn{2}{|c|}{$\begin{array}{c}46.6 \pm 9.2 \\
(29-67)\end{array}$} & \multicolumn{2}{|c|}{$\begin{array}{c}45.5 \pm 11.3 \\
(25-69)\end{array}$} & \\
\hline \multirow[t]{2}{*}{ Gender } & Male & 26 & 66.7 & 27 & 65.9 & 20 & 50.0 & 0.228 \\
\hline & Female & 13 & 33.3 & 14 & 34.1 & 20 & 50.0 & \\
\hline \multicolumn{9}{|c|}{ * Significant difference between percentages using Pearson Chi-square test ( $\chi 2$-test) at 0.05 levels. } \\
\hline \multicolumn{9}{|c|}{ \#Significantdifference between two independent means using Students-test at 0.05 levels. } \\
\hline & & & & & & & & \\
\hline
\end{tabular}

Table 1. Demographic data of Diabetic acromegalic, nondiabetic acromegalic patients and control group (non- acromegalic nondiabetic counterparts). 


\begin{tabular}{|c|c|c|c|c|c|c|c|}
\hline & & \multicolumn{6}{|c|}{ Neopterin $(\mathrm{pg} / \mathrm{mL})$} \\
\hline & & \multicolumn{2}{|c|}{$\begin{array}{c}\text { Diabetic } \\
\text { Acromegaly }\end{array}$} & \multicolumn{2}{|c|}{ Nondiabetic Acromegaly } & \multicolumn{2}{|c|}{ Healthy control } \\
\hline & & No & Mean \pm SD & No & Mean \pm SD & No & Mean \pm SD \\
\hline \multirow{6}{*}{$\begin{array}{c}\text { Age } \\
\text { (years) }\end{array}$} & $<30$ years & - & - & 1 & $20.025 \pm$ & 4 & $30.483 \pm 18.916$ \\
\hline & $30---39$ & 3 & $162.571 \pm 154.151$ & 9 & $84.189 \pm 80.716$ & 7 & $32.508 \pm 28.097$ \\
\hline & 40----49 & 18 & $110.488 \pm 125.313$ & 12 & $56.617 \pm 44.303$ & 16 & $43.710 \pm 31.496$ \\
\hline & $50--59$ & 10 & $67.980 \pm 59.796$ & 16 & $63.288 \pm 22.261$ & 9 & $55.308 \pm 29.230$ \\
\hline & $\Rightarrow 60$ years & 8 & $71.699 \pm 36.871$ & 3 & $122.303 \pm 101.851$ & 4 & $31.197 \pm 28.324$ \\
\hline & P-value & & 0.417 & & 0.268 & & 0.444 \\
\hline \multirow{3}{*}{$\begin{array}{l}\text { Age } \\
\text { (years) }\end{array}$} & $<50$ years & 21 & $117.928 \pm 126.779$ & 22 & $66.233 \pm 61.666$ & 27 & $38.846 \pm 28.843$ \\
\hline & $\Rightarrow>50$ years & 18 & $69.633 \pm 49.561$ & 19 & $72.606 \pm 45.325$ & 13 & $47.889 \pm 30.072$ \\
\hline & $\mathrm{P}$-value & & 0.138 & & 0.712 & & 0.365 \\
\hline \multirow[t]{3}{*}{ Gender } & Male & 26 & $113.014 \pm 118.276$ & 27 & $70.571 \pm 45.285$ & 20 & $37.078 \pm 28.277$ \\
\hline & Female & 13 & $60.888 \pm 32.328$ & 14 & $66.517 \pm 70.044$ & 20 & $46.492 \pm 30.018$ \\
\hline & P-value & & 0.129 & & 0.823 & & 0.314 \\
\hline \multicolumn{8}{|c|}{ \#Significant difference between two independent means using Students-t-test at 0.05 level. } \\
\hline
\end{tabular}

Table 2. Neopterin concentration in Diabetic acromegalic, nondiabetic acromegalic and control group according to age, gender, duration of disease.

\begin{tabular}{|c|c|c|c|c|c|c|c|}
\hline & & \multicolumn{6}{|c|}{ Neopterin $(\mathrm{pg} / \mathrm{mL})$} \\
\hline & & \multicolumn{2}{|r|}{$\begin{array}{c}\text { Diabetic } \\
\text { Acromegaly }\end{array}$} & \multicolumn{2}{|c|}{ Nondiabetic Acromegaly } & \multicolumn{2}{|r|}{$\begin{array}{l}\text { Healthy } \\
\text { control }\end{array}$} \\
\hline & & No & Mean \pm SD & No & Mean \pm SD & No & Mean \pm SD \\
\hline \multirow{3}{*}{$\begin{array}{l}\text { HDL } \\
(\mathrm{mg} / \mathrm{dL})\end{array}$} & Low & 25 & $90.253 \pm 110.943$ & 17 & $63.412 \pm 61.999$ & 1 & $4.328 \pm$ \\
\hline & $\begin{array}{l}\text { Normal } \\
(35-70)\end{array}$ & 14 & $105.255 \pm 82.462$ & 24 & $73.277 \pm 48.802$ & 39 & $42.745 \pm 28.910$ \\
\hline & $P$ value & & 0.662 & & 0.572 & & 0.197 \\
\hline \multirow{4}{*}{$\begin{array}{l}\mathrm{LDL} \\
(\mathrm{mg} / \mathrm{dL})\end{array}$} & Low & 3 & $71.774 \pm 40.778$ & 8 & $74.157 \pm 71.995$ & 25 & $44.722 \pm 29.543$ \\
\hline & $\begin{array}{l}\text { Normal } \\
(65-170)\end{array}$ & 32 & $89.175 \pm 90.928$ & 28 & $68.356 \pm 51.048$ & 15 & $36.889 \pm 28.880$ \\
\hline & High & 4 & $165.244 \pm 185.981$ & 5 & $65.885 \pm 50.831$ & - & - \\
\hline & $P$ value & & 0.340 & & 0.957 & & 0.418 \\
\hline \multirow{3}{*}{$\begin{array}{l}\text { VLDL } \\
(\mathrm{mg} / \mathrm{dL})\end{array}$} & Low & 39 & $95.638 \pm 100.763$ & 41 & $69.187 \pm 54.141$ & 40 & $41.785 \pm 29.176$ \\
\hline & $\begin{array}{l}\text { Normal } \\
(65-170)\end{array}$ & - & - & - & - & - & $\mathrm{zl}-$ \\
\hline & $P$ value & & - & & - & & - \\
\hline \multirow{3}{*}{$\begin{array}{l}\text { Cholester } \\
\text { ol } \\
(\mathrm{mg} / \mathrm{dL})\end{array}$} & $\begin{array}{l}\text { Normal } \\
(<200)\end{array}$ & 23 & $87.480 \pm 72.162$ & 25 & $73.278 \pm 63.979$ & 40 & $41.785 \pm 29.176$ \\
\hline & High & 16 & $107.366 \pm 133.549$ & 16 & $62.794 \pm 34.582$ & - & - \\
\hline & $P$ value & & 0.551 & & 0.552 & & - \\
\hline \multirow{3}{*}{$\begin{array}{l}\text { Triglyceri } \\
\text { de } \\
(\mathrm{mg} / \mathrm{dL})\end{array}$} & $\begin{array}{l}\text { Normal } \\
(40-140)\end{array}$ & 6 & $143.365 \pm 167.084$ & 10 & $84.355 \pm 76.048$ & 31 & $46.242 \pm 29.962$ \\
\hline & High & 33 & $86.961 \pm 84.795$ & 31 & $64.293 \pm 45.518$ & 9 & $26.432 \pm 21.003$ \\
\hline & $P$ value & & 0.211 & & 0.314 & & 0.072 \\
\hline \multicolumn{8}{|c|}{ \#Significant difference between two independent means using Students-t-test at 0.05 level. } \\
\hline
\end{tabular}

Table 3. Neopterin concentration in Diabetic acromegalic, nondiabetic acromegalic and control group according to lipid profile. 


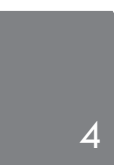

\begin{tabular}{|c|c|c|c|c|c|c|c|}
\hline & & \multicolumn{6}{|c|}{ Neopterin $(\mathrm{pg} / \mathrm{mL})$} \\
\hline & & \multicolumn{2}{|c|}{ Diabetic Acromegaly } & \multicolumn{2}{|c|}{ Nondiabetic Acromegaly } & \multicolumn{2}{|c|}{$\begin{array}{c}\text { Healthy } \\
\text { control }\end{array}$} \\
\hline & & No & Mean \pm SD & No & Mean \pm SD & No & Mean \pm SD \\
\hline \multirow[t]{3}{*}{$\begin{array}{l}\mathrm{HbAlc} \\
(\%)\end{array}$} & $\begin{array}{l}\text { Normal } \\
(4.2-6.2 \%)\end{array}$ & 2 & $94.946 \pm 73.644$ & 31 & $56.573 \pm 32.121$ & 40 & $41.785 \pm 29.176$ \\
\hline & High & 37 & $95.676 \pm 102.794$ & 10 & $108.287 \pm 85.685$ & - & - \\
\hline & $P$ value & & 0.992 & & $0.007 \#$ & & - \\
\hline \multirow{4}{*}{$\begin{array}{l}\mathrm{GH} \\
(\mathrm{ng} / \mathrm{mL})\end{array}$} & Low & 2 & $77.000 \pm 20.648$ & 2 & $36.957 \pm 40.549$ & 37 & $44.429 \pm 28.720$ \\
\hline & $\begin{array}{l}\text { Normal } \\
(0.4-10 \mathrm{AM} \text {; } \\
1-14 \mathrm{AF})\end{array}$ & 37 & $96.646 \pm 103.369$ & 38 & $72.323 \pm 54.565$ & 3 & $9.180 \pm 5.370$ \\
\hline & High & - & - & 1 & $14.460 \pm$ & - & - \\
\hline & $P$ value & & 0.792 & & 0.405 & & $0.043 \#$ \\
\hline \multirow{4}{*}{$\begin{array}{l}\text { IGF-1 } \\
(\mathrm{ng} / \mathrm{mL})\end{array}$} & Low & - & - & - & - & - & - \\
\hline & $\begin{array}{l}\text { Normal } \\
(200-450)\end{array}$ & 36 & $89.859 \pm 96.013$ & 38 & $71.126 \pm 55.792$ & 40 & $41.785 \pm 29.176$ \\
\hline & High & 3 & $164.992 \pm 154.175$ & 3 & $44.620 \pm 7.940$ & - & - \\
\hline & $P$ value & & 0.219 & & 0.421 & & - \\
\hline \multirow{4}{*}{$\begin{array}{l}\text { Interferon } \\
\text {-gamma } \\
(\mathrm{ng} / \mathrm{mL})\end{array}$} & Low & - & - & - & - & - & - \\
\hline & $\begin{array}{l}\text { Normal } \\
(1.2-80)\end{array}$ & - & - & 1 & $7.475 \pm$ & 1 & $43.120 \pm$ \\
\hline & High & 39 & $95.638 \pm 100.763$ & 40 & $70.729 \pm 53.910$ & 39 & $41.751 \pm 29.557$ \\
\hline & $P$ value & & - & & 0.254 & & 0.964 \\
\hline \multicolumn{8}{|c|}{ \#Significant difference between two independent means using Students-t-test at 0.05 level. } \\
\hline
\end{tabular}

Table 4. Neopterin concentration in Diabetic acromegalic, non- diabetic acromegalic and control group according to $\mathrm{HbA1C}$, $\mathrm{GH}, \mathrm{IGF}-1$ and Interferon - gamma.

quency of acromegaly in the elderly, most likely as a result of longer life expectancy. There is a delay in diagnosis, as there is in the younger population with acromegaly, which is exacerbated by the similarities between the aging process and some of the disease's symptoms. As one might assume, comorbidities are more common in senior people with acromegaly than in younger patients. The diagnostic criteria for older patients are the same ${ }^{2}$. In the current study, males represent (66.3\%) of enrolled patients while females are only (33.7\%); this result is similar to other studies, the rote of Transsphenoidal- selective adenomectomy (TSA) is $89.7 \%$ and $76.5 \%$ in males and females, respectively $(\mathrm{P}, 0.001)^{15}$.

Statin use reduces the neopterin level; statin reduces the neopterin level plus the well-known cardiovascular protective effect. This may be related to the fact that neopterin is a soluble marker of monocyte activation, and monocyte activation has been linked to the pathogenesis of coronary artery disea$\mathrm{se}^{16}$. In diabetic, acromegalic subjects normal HDL is associated with an increment in neopterin; some investigators pointed out to the fact that neopterin is associated with reduced HDL levels. However, it shows no association with other markers of metabolic syndrome, namely waist-hip ratio ${ }^{17}$. Poor glycemic is associated with a decrement in neopterin level; it has been found that neopterin level is elevated in people with insulin resistance ${ }^{18}$. Neopterin is found to be high among patients with high of IGF-1.once neopterin, and IGF-1 were found to be high in elderly patients hospitalized, followed by delirium, and it has been proposed that oxidative stress and activation of the immune system may be the cause of an increase in both biomarkers ${ }^{18}$

\section{Conclusions}

Neopterin has the highest level among acromegalic diabetics, followed by a nondiabetic acromegalic and the control, respectively. Neopterin is higher in males with DM and acromegaly. Elevation of Triglyceride ( $>150 \mathrm{mg} / \mathrm{dL}$ ) is associated with the high neopterin in diabetic acromegalic followed by nondiabetic acromegalic and control group. People with diabetes with poor glycemic control have low neopterin, but the contrary is true for nondiabetic subjects where the progressive increment of $\mathrm{HbAlc}$ is associated with higher neopterin levels. However, those subjects did not the definition of diabetes ( $\mathrm{HbAlc}<6.5 \%)$. A well designed prospective study enrolling a higher number of acromegalic subjects is highly recommended to find out the impact of neopterin on the progression of acromegaly and its mortality to find out a modal of therapy that modulates the level of this molecule fruitfully, the sometimes it may be prudent to find out if neopterin has any relation with other molecules as IGF-land GH and the reflection of these molecules on acromegaly and its comorbidities and mortality. 


\section{Bibliographic references}

1. Sesmilo, G. et al. Changes in acromegaly treatment over four decades in Spain: Analysis of the Spanish Acromegaly Registry. Pituitary. (2013).16, 115-121.

2. Jallad, R.S. and Marcello, D.B. Acromegaly in the elderly patient. Arch Endocrinol Metab. (2019).63/6, 638 - 645.

3. Olarescu, N. C. \& Bollerslev, J. . The Impact of Adipose Tissue on Insulin Resistance in Acromegaly. Trends in Endocrinology \& Metabolism. (2016).27, 226-237.

4. Pivonello R, Auriemma RS, Grasso LF, Pivonello C, Simeoli C, Patalano R, Galdiero M, Colao A . Complications of acromegaly: cardiovascular, respiratory and metabolic comorbidities. Pituitary. (2017). 20:46-62.

5. Ferraù, F., Albani, A., Ciresi, A., Giordano, C., \& Cannavò, S. Diabetes Secondary to Acromegaly: Physiopathology, Clinical Features and Effects of Treatment. Frontiers in endocrinology,(2018). 9, 358.

6. Pingle, Shubhangi, et al.: "Neopterin: Biomarker of cell-mediated immunity and potent usage as biomarker in silicosis and other occupational diseases." Indian Journal of Occupational and Environmental Medicine, (2008).vol. 12, no. 3, 2008, p. 107.

7. Grammer TB, Fuchs D, Boehm BO, Winkelmann BR, Maerz W.: Neopterin as a predictor of total and cardiovascular mortality in individuals undergoing angiography in the Ludwigshafen risk and cardiovascular health study. Clin Chem.(2009). 55:1135-46.

8. Sucher R, Schroecksnadel K, Weiss G, Margreiter R, Fuchs D, Brandacher G.: Neopterin, a prognostic marker in human malignancies. Cancer Lett. (2010). 287:13- 22.

9. Oxenkrug GF.: Interferon-gamma-inducible kynurenines/pteridines inflammation cascade: implications for aging and aging-associated psychiatric and medical disorders. J Neural Transm. (2011).118:75-85.

10. Oxenkrug G, Tucker KL, Requintina P, Summergrad P.: Neopterin, a marker of interferon-gamma-inducible inflammation, correlates with pyridoxal-5'- phosphate, waist circumference, hdl-cholesterol, insulin resistance and mortality risk in adult boston community dwellers of Puerto Rican origin. Am J Neuroprot Neuroregen. (2011). 3:48-52.
11. Murr C, Widner B, Wirleitner B, Fuchs D.: Neopterin as a marker for immune system activation. Curr Drug Metab.(2002). 3:175-87.

12. Melmed S. Tight control of growth hormone: an attainable outcome for acromegaly treatment.JClin Endocrinol Metab. (1998);83;3409-3410.

13. Qasim. B. :Duhok/IRAQ acromegaly; one year of experience. Endocrine Abstracts (2017) 49 EP94.

14. Hammood, S.D.: Serum Osteopontin and Osteoprotegerin levels in a sample of Iraqi patients with acromegaly and type 2 diabetes mellitus. Master thesis, Clinical Biochemistry, College of Medicine, Mustansiriyah University, Iraq.(2020).

15. Park, S.E., Cheol, R.K., Ju, H.M., Eui, H.K., Sun, H. K. and Eun, J. L.: Age- and Sex-Specific Differences as Predictors of Surgical Remission Among Patients With Acromegaly . J ClinEndocrinolMetab.(2018). 103(3):909-916.

16. Ray, K. K., Morrow, D. A., Sabatine, M. S., Shui, A., Rifai, N., Cannon, C. P., \& Braunwald, E.: Long-term prognostic value of neopterin: a novel marker of monocyte activation in patients with acute coronary syndrome. Circulation,(2016).115(24), 3071-3078.

17. Chuang, S. C., Boeing, H., Vollset, S. E., Midttun, Ø., Ueland, P. M., Bueno-de-Mesquita, B. \& Aleksandrova, K. :Cellular immune activity biomarker neopterin is associated hyperlipidemia: results from a large population-based study. Immunity \& Ageing,(2016).13(1), 1-11.

18. Gürcü, S., Girgin, G., Yorulmaz, G., Kılıçarslan, B., Efe, B., \& Baydar, T. : Neopterin and biopterin levels and tryptophan degradation in patients with diabetes. Scientific reports,(2020).10(1), 1-8.

19. Egberts, A., Wijnbeld, E. H., Fekkes, D., Van Der Ploeg, M. A., Ziere, G., Hooijkaas, H., ... \& Mattace-Raso, F. U. : Neopterin: a potential biomarker for delirium in elderly patients. Dementia and geriatric cognitive disorders, (2015).39(1-2), 116-124.. 